\title{
RELATIONS OF SECONDARY STUDENTS' INTRINSIC MOTIVATION AND ASPIRATIONS WITH THEIR ACHIEVEMENT IN SCIENCE
}

\author{
N. W. L. Narangodaa ${ }^{1}$, W. D. Chandrasenab ${ }^{2} \square$ (iD) H. M. S. P. Madawala ${ }^{3}$ (iD \\ 1, 2 Postgraduate Institute of Science, University of Peradeniya, Peradeniya, Sri Lanka. \\ ${ }^{3}$ Department of Botany, Faculty of Science, University of Peradeniya, Peradeniya, Sri Lanka.
}

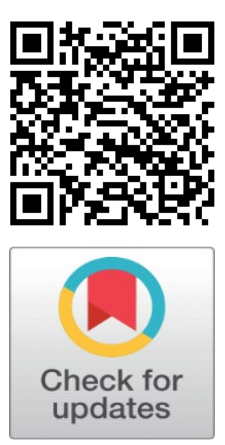

Received 14 September 2021

Accepted 16 October 2021

Published 31 October 2021

\section{Corresponding Author}

W. D. Chandrasenab, wdchand@pdn.ac.lk

\section{DOI}

10.29121/granthaalayah.v9.i10.2021 .4329

Funding: This research received no specific grant from any funding agency in the public, commercial, or not-for-profit sectors.

Copyright: (C) 2021 The Author(s). This is an open access article distributed under the terms of the Creative Commons Attribution License, which permits unrestricted use, distribution, and reproduction in any medium, provided the original author and source are credited.

\section{ABSTRACT}

Science has brought about revolutionary changes in every aspect of life. Its impact is visible everywhere and in every practice of our existence. Thus, science education is a valuable resource in this world. If students have intrinsic motivation, they are active, curious, interested and eager to engage in learning process and the intrinsically motivated behaviors help them acquire knowledge and experience in science. Moreover, educational aspirations and career aspirations are enhanced through better science education. Thus, the present study aimed to investigate the relations of secondary students' intrinsic motivation and aspirations with their achievement in science. This is a mixed methods study and sample consisted of 2384 students in Grade 8 and Grade 9. Hence, an intervention was implemented to explore students' intrinsic motivation, aspirations using suitable teaching methodologies and strategies. The results reveal that, there were strong positive relationships of students' intrinsic motivation and aspirations with their achievement $\left(\mathrm{r}^{2}=.691\right.$; .687 respectively) in the experimental group. However, there were very low positive relationship of students' intrinsic motivation and aspirations with their achievement $\left(\mathrm{r}^{2}=.012 ; .006\right.$ respectively) in the control group. Further, there were significant differences of students' intrinsic motivation, aspirations and achievement before and after the intervention in the experimental group; $\mathrm{t}=48.513$ (1132) $p=.000 ; \mathrm{t}=53.689$ (1132) $p=.000 ; \mathrm{t}=65.939$ (1132) $p=.000$ respectively. However, there were no such significant differences of the above aspects before and after the intervention in the control group; $\mathrm{t}=-.989$ (1250) $p=.323 ; \mathrm{t}=1.575$ (1250) $p=.116 ; \mathrm{t}=.968(1250) p=$ .333 respectively. The findings of the study provided comprehensive understanding of the above relations, develop suitable teaching and learning methodologies and inform the practice in science education.

Keywords: Intrinsic Motivation, Aspirations, Achievement

\section{INTRODUCTION}

Science has been simply defined as an organized body of knowledge. Further, as science knowledge is contestable, continuously subject to revision, refinement and extension (Ferrari, 2011), the dissemination and digestion of new scientific knowledge is very important. As such, advances in science impact everybody in the world and we cannot expect the development of technology without science. Despite the recognized need for better science education, the number of students pursuing science post-schooling continues to decline internationally. Knowledge of science and mathematics is the basis for personal accomplishment and responsible citizenship, social and economic development and it is benchmark of innovation, entrepreneurship and competitiveness in global world (Gilbert (1991)). Hence, science education is very important aspect to everyone. 
Science education includes cultural enterprises which form a part of the wider cultural matrix of society and that educational considerations concerning science must be made in the light of this wider perspective (Aikenhead (1996)). Science education is important to provide new ways of thinking and identifying solutions to problems. This requires new ways of working and strengthens links and interaction between formal, non-formal and informal science education (Gilbert (1991)). Hence, the goal of science education, thus, should be improved students' understanding of scientific knowledge and the practical aspects of science education in building a scientifically literature society. Past research has shown that the decline in science enrolments is related to many interrelated factors, such as: students' academic abilities, teaching methods, the absence of motivation to study science, and a lack of interest in science subject (Hassan and Treagust, 2003). Students' intrinsic motivation and aspirations could also be related to the decline in the number of students seeking to pursue science. However, a comprehensive study has not been conducted to identify key psychosocial drivers and to investigate the relations between such drivers and engagement in science. This is unfortunate, as psychosocial constructs may serve as the drivers of desirable educational outcomes in science (Chandrasena (2013)). For example, intrinsic motivation, aspirations have been demonstrated by a body of international research to be key drivers.

According to the Self-Determination Theory, intrinsic motivation refers to activities that are done for their inherent satisfaction. Thus, an understanding of intrinsic motivation must consider how the characteristics of an activity and context are experienced and engaged in by the individual in question. An individual will be intrinsically motivated for an activity to the degree that he or she finds it inherently interesting and enjoyable, which is in turn a function of proximal basic need satisfaction (Deci et al. (2012)). In this aspect, teacher has a great responsibility to enhance students' intrinsic motivation for the future performance. Teachers choose to motivate students powerfully affects the students' interest, engagement, selfconcept, wellbeing in the classroom (Ryan and Deci (2000)). On the other hand Ryan et al. (1990) showed a relation between intrinsic motivation and learning. Students who were intrinsically motivated for the reading who found it interesting and enjoyable subsequently did better on an unexpected test. Hence teachers who are autonomy supportive effectively facilitate intrinsic motivation.

Education aspiration is sum of other level of aspiration goals, such as career goals, occupational goals, life style wealth etc. Every student has educational aspiration. It is a decision which the individual inspires about what he or she wants to become in life and what course he or she wants to study. Science understanding and ability also enhance the capability of students to hold meaningful and productive careers in the future. It means career aspiration of the students affects to the future careers and it may provide fruitful life in their future. The future world needs entry level workers with the ability to inspire reasons, think creatively, make decisions, analyze and solve problems according to the scientific method. Students' motivation aspirations are positively correlated to students' achievements (Chandrasena (2013)). In this aspect, the teaching methodologies and strategies were used to enhance students' intrinsic motivation, aspirations and achievements. Thus, in the recent investigation, teaching methodologies are well developed to enhance students' educational aspirations careers aspirations and also intrinsic motivation in science.

However, there is a dearth of research investigation relations among students intrinsic motivation, aspirations in different domains in science in the Sri Lankan context. On the other hand, a comprehensive study has not been conducted to identify key psychological drivers that influence the uptake of science education. 
Thus, the main aim of the present study was to address this gap in the literature by investigation the relations of secondary students' intrinsic motivation and aspirations with their achievement in science.

\section{RESEARCH AIM, OBJECTIVES, RESEARCH QUESTIONS AND THEIR RATIONALE \\ 2.1. RESEARCH AIM}

The main aim of the present study was to investigate the relations of secondary students' intrinsic motivation and aspirations with their achievements in science to make suggestions to enhance students' meaningful learning in science in Sri Lanka.

\subsection{RESEARCH OBJECTIVES}

1) To investigate the students' intrinsic motivation, and aspirations before intervention.

2) To investigate the students' level of achievement.

3) To use different methods of teaching for experimental and control groups.

4) To determine the relations of students' intrinsic motivation and aspirations with their achievement in science in both experimental and control groups.

5) To make suggestions to enhance meaningful learning in Grade 8 and Grade 9 science students in Sri Lanka.

\subsection{RESEARCH QUESTIONS}

1.1What are the students' existing intrinsic motivation, and aspirations?

2.1 What are the students' levels of achievement?

3.1 What are the teaching methods used to be teach selected lessons to improve students' intrinsic motivation, aspirations and achievement in science in the experimental groups?

3.2 What are the teaching methods used to be teach selected lessons in the control group?

4.1 What are the students' intrinsic motivation, aspirations and achievement after the intervention in experimental group?

4.2 What are the students' intrinsic motivation, aspirations and achievement after the intervention in control group?

4.3 What are the relations of students' intrinsic motivation and aspirations with their achievement in science?

5.1 What are the suggestions can be made towards meaningful learning in science in Grade 8 and Grade 9 in Sri Lanka?

\subsection{RATIONALE}

Science education leads to individual livelihoods in any number of scientific persuasions, a general understanding of the scientific and technological foundations of the world we live in is just as prevalent to almost any other employment, and to daily life. The burning issue of declining students' admission in science must be addressed, to ensure that science is advanced in Sri Lanka. Today's science students are tomorrow's inventors, entrepreneurs, medical researchers, engineers, teachers and leaders to promote the country in the global level.

Past research in other countries, suggests that the decline in science education is related to students' motivation, academic abilities, and teaching methods (Hassan 
and Treagust, 2003). However, a comprehensive study has not been conducted to identify key psychological drivers and to investigate the relations between such drivers and engagement in science in Sri Lanka. However, there is a dearth of research investigation relations among students' intrinsic motivation, and aspirations in different domains in science in the Sri Lanka content. On the other hand, a comprehensive study has not been conducted to identify key psychological drivers that influence the uptake of science education. Thus, the main aim of the present study was to address this gap in the literature by investigation the relations of secondary students' intrinsic motivation and aspirations with their achievement in science.

\section{METHODOLOGY}

\subsection{METHOD}

The research used mixed methods of study. It is a type of research in which researcher combines elements of qualitative and quantitative research approaches for the purpose of greater validity and triangulations. As such both qualitative and quantitative approaches were used in the process of data collection and data analysis. The research design was the experimental research design. Items of questionnaires were carefully chosen that addressed domains of secondary students' intrinsic motivation, and aspirations related to science. Pretest papers and posttest papers were prepared to examine the achievements of students in science before intervention and after the intervention respectively.

\subsection{DATA COLLECTION}

Sampling: A focus of this research was to examining the relations of secondary students' intrinsic motivation and aspirations with their achievements in science. To fulfill this goal convenience sampling technique was used. Participants comprised 2384 students from Grade 8 and Grade 9 at 19 1AB schools and 1C schools in Dehiowita and Kegalle educational zones at Sabaragamuwa province. Control group and experimental group consisted with 1151 students and 1233 students respectively.

Procedure: Ethical approval were obtained from the director of postgraduate institute of science, University of Peradeniya; the directress of zonal education, Dehiowita educational zone, the director of zonal education, Kegalle educational zone, relevant school principals and the participants (students). Students were divided into two groups as control and experimental groups based on pretest marks. Different teaching- learning methodologies and strategies were applied to experimental and control groups separately according to the lesson plans. Lesson plans were prepared for the lessons of classification of animals, diversity of plants, photosynthesis, life cycles of animal and food preservations in Grade 8 and usages of microorganisms, human eye and ear, human blood circulatory system in grade 9. Discussions, debates, role playing, games, writing and speaking exercise, classroom assessments, group works, presentations and practical were used as teaching methodologies for the experimental group in the intervention and traditional teaching method was used for the control group. Students' intrinsic motivation and aspirations were measured before intervention and after intervention in both groups using same multidimensional questionnaire. Posttests were given after the intervention to measure the students' achievements. There were two types of posttests as multiple choice question papers and structured essay papers. The achievements were measured in getting average marks of posttests. Focus group interviews were conducted with small groups of students both Grade 8 and 9 and 
the interview data were transcribed in the same day. Photographs were obtained while the intervention process and these were transcribed also the same day that they take.

At the beginning of the intervention it was announced to the students that the data collected would only be used by the researcher for research purposes without reporting back the raw data to the schools, parents and other people. Students' were also informed that the consent form they sign in the questionnaire booklet will be removed and stored separately after the research in order to make students' answers confidential without giving others the chance to identify the individuals.

Instrumentation: Students' existing intrinsic motivation and aspirations were measured by revised validated multidimensional questionnaire. The likert items were used and scale was 7 . The same questionnaire was used to measure above factors after the intervention in both experimental and control groups. It comprised 6 items for intrinsic motivation, 6 items for self-concepts and 7 items for aspirations (3 items for educational aspirations and 4 items for career aspirations). Pretest papers were prepared to measure students existing achievement in Grade 8 and 9 separately. Posttest papers were prepared as multiple choice question papers and structured essay question papers separately. Students' science marks sheets, registers, Grade 8 and 9 text books, Grade 8 and 9 teachers' instruction manuals were use as documents in data collection.

Focus group interviews and photographs were used as qualitative aspect. Focus group interviews were conducted in every school with 5-6 students in both Grade 8 and 9 in the experimental group. Photographs were taken in everyday in the intervention process in both Grade 8 and 9 in the experimental group.

\subsection{DATA ANALYSIS}

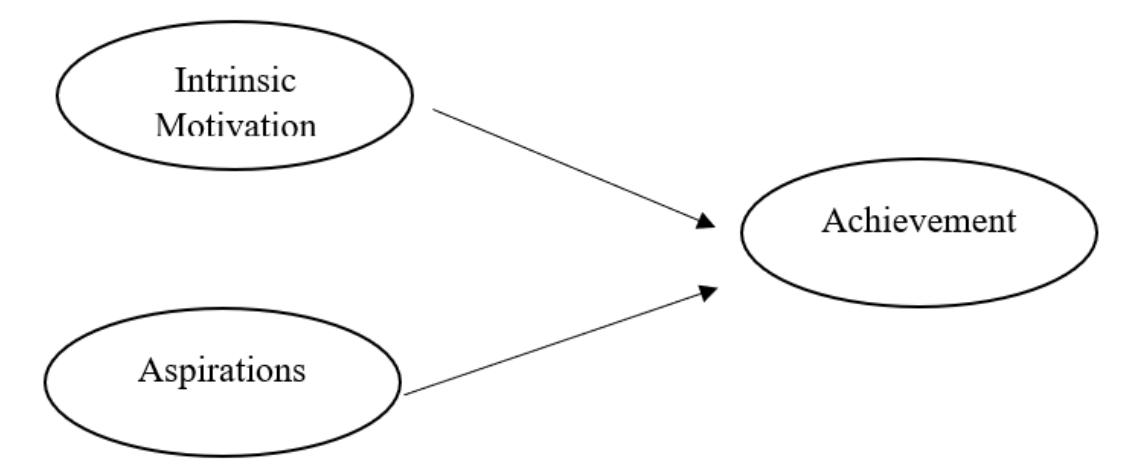

Figure 1 Independent Variables and Dependent Variable of the Study

Quantitative data were initially entered in Microsoft Excel sheets were prepared for use in SPSS. Data screening and general analyses (reliabilities, frequencies etc.) were performed using SPSS.22.0.

Descriptive analyses were carried out on the data for students' intrinsic motivation and aspirations (mean values) followed by reliability test. Chronbatch's alpha values were used to measure internal consistency and reliability of the above factors. The differences between before intervention and after intervention of students' intrinsic motivation and aspirations were measured by pared sample ttest (95\% confidence level) and differences of achievements (pretest and posttests) were measure by pared sample t-test ( $95 \%$ confident level). Correlation of intrinsic motivation with achievements and aspirations with achievement before intervention and after intervention were measured by linear regression with $\mathrm{r}^{2}$ 
values in both the control group and the experimental group. Independent variables were students' intrinsic motivation and aspirations and the dependent variable was students' achievements. Thematic analysis was used to analyze the qualitative data. Students' focus group interviews were recorded using voice recorder of the mobile phone. The data in these were transcribed, each focus group interview recording being played over several times. They were later transcribed to a Microsoft word document. Then, codes and themes were derived.

\section{RESULTS AND DISCUSSION}

Cronbach's alpha is a measure of internal consistency and reliability which is how closely related a set of items are as a group. Reliability is the degree to which the result of a measurement, calculation, or specification can be depended on to be accurate. Alpha coefficients were ranged between 0.93 and 0.96 of these factors of the multidimensional questionnaire. Thus, the internal consistency or reliability of those items is excellent $(\geq 0.5)$ in the questionnaire and it can be used as stranded instrument of data collection.

\begin{tabular}{|cc|}
\hline Table 1 Reliability statistic of intrinsic motivation and aspirations \\
\hline Factor & Cronbach's alpha \\
\hline Intrinsic Motivation & .937 \\
Aspirations & .965 \\
\hline
\end{tabular}

The above Cronbach's alpha values show high degree of reliability of the instrument used.

\section{Research Question 1.1: Students' existing intrinsic motivation and aspirations in the experimental and control group}

Descriptive statistics were done to measure mean values of existing students' intrinsic motivation, and aspirations and of the both experimental and control groups. Mean statistics of existing intrinsic motivation and aspirations in the experimental group were represented in Table 2 .

\begin{tabular}{ccccccc}
\hline $\begin{array}{l}\text { Table } \\
\text { experimental group }\end{array}$ & $\begin{array}{c}\text { Mean statistics } \\
\text { of }\end{array}$ & N & Range & Minimum & Maximum & Mean statistics \\
\hline MMBE & 1233 & 5 & 1 & 6 & 2.7583 \\
MABE & 1233 & 5 & 1 & 6 & 2.5134 \\
\hline
\end{tabular}

NB: $M M B E=$ mean value of motivation before intervention in experimental group, MABE= mean value of aspirations before intervention in experimental group.

Mean values of all three factors were around 2.5. The median value of this range was 3 . But the mean values were less than the median. Hence, students existing intrinsic motivation, and aspirations were low towards science in the sample of experimental group. 


\section{Research Question 2.1: Students' existing achievements in the experimental and control groups}

In this aspect, descriptive statistics were done students' existing achievements in the experimental group. It was represented in Table 3.

\begin{tabular}{|ccccccc}
\hline \multicolumn{4}{|c}{ Table 3 Mean statistics of students' existing achievements in the experimental group } \\
\hline & N & Range & minimum & maximum & Mean statistic \\
\hline PRETEST & 1233 & 28 & 1 & 29 & 11.44 \\
\hline
\end{tabular}

NB: PRETEST=students' existing achievements

The mean statistics of the existing achievements of students in the experimental group was lower than the median of the range. Thus, the students' existing achievements was low in the experimental group. On the other hand, mean statistics of existing intrinsic motivation and aspirations in the control group were represented in Table 4.

\begin{tabular}{cccccc}
\hline \multicolumn{5}{|c}{ Table } \\
\hline & $\mathbf{N}$ & Mean statistics of intrinsic motivation and aspirations of control group \\
\hline MMBC & 1151 & 5 & minimum & maximum & Mean statistics \\
MABC & 1151 & 5 & 1 & 6 & 2.5777 \\
\hline
\end{tabular}

NB: $M M B C=$ mean value of intrinsic motivation before intervention in control group, $\mathrm{MABC}=$ mean value of aspirations before intervention in control group.

Mean values of these two factors were around 2.5. The median value of this range was 3 . In this aspect, the mean values were less than the median. Hence, students existing intrinsic motivation and aspirations were low towards science in the sample of the control group.

Mean descriptive of intrinsic motivation and aspirations were ranged 2.513 to 2.758 in experimental group and also mean descriptive of intrinsic motivation and aspirations were ranged 2.371 to 2.577 in control group. In this aspect, there is no difference between students' existing intrinsic motivation and aspirations of experimental group and control group. On the other hand, students' existing achievements were measured before intervention in the control group and the results were represented in the following Table 5.

\begin{tabular}{|lcccccc}
\hline \multicolumn{4}{|c|}{ Table 5 Mean statistics of students' existing achievements in the control group } \\
\hline
\end{tabular}

NB: PRETEST=students' existing achievements

The results revealed that, the existing achievements of the students of control group were low and there were no difference between existing achievements of the students in both experimental and control group. 
Research Question 3.1: Teaching and learning methodologies in the study.

In this aspect, to empower the students' intrinsic motivation and aspirations, teaching methodologies and teaching strategies were applied. Teacher centered classroom was shifted to student centered classroom. According to the Self Determination Theory, positive reinforcements, positive feedback and other positive extrinsic events were established while the teaching learning process. Rapport was buildup with students and given mental and emotional support to the students. Dorothy (1989) was argued that to enhance students' aspirations by helping students develop academically, make responsible decisions, resolve conflict, take risks, develop leadership skills, behave responsibility and make informed choices about their careers and lifestyles. Hence, discussions, debates, role playing, games, writing and speaking exercise, classroom assessments, group works, presentations and practical were used as teaching methodologies for the experimental group in the intervention. Activities, assessments, home works and other events in the teaching learning process were developed to suit all three types of learners such as auditory learners, visual learners and kinesthetic learners in the classroom. Laboratories, classrooms, outdoor fields, home science room and computer labs were used to follow above methodologies.

On the other hand, traditional teaching- learning process was used for control group. The classroom was teacher centered. On this aspect, students' intrinsic motivation, and aspirations were measured before and after intervention using the same multidimensional questionnaire.

\section{Research Question 4.1: Students' intrinsic motivation, aspirations and achievements after the interventions in the experimental group}

The descriptive statistics of these two factors were given in the following Table 6.

Table 6 Descriptive statistics of intrinsic motivation and aspirations after interventions in the experimental group

$\begin{array}{llllll} & \text { N } & \text { Range } & \text { Minimum } & \text { Maximum } & \text { Mean statistics } \\ \text { MMAE } & 1233 & 5.00 & 1.00 & 6.00 & 5.8154 \\ \text { MAAE } & 1233 & 5.00 & 1.00 & 6.00 & 5.7646\end{array}$

NB: MMAE: mean intrinsic motivation after intervention of the experimental group, MAAE: mean aspirations after intervention of the experimental group.

The maximum value of this range was 6 . In this aspect, mean values of these two factors were around 6 in the experimental group. Therefore, students' mean values of intrinsic motivation, and aspirations were increased through the intervention process in the experimental group. It means, the teaching methodologies and strategies which were used in the intervention were fruitful and effective. According to the Bomia et al. (1997), teaching strategies support the learners' intrinsic motivation and other emotional and mental concepts, specific teaching strategies have a positive effect on the various concept related to intrinsic motivation. Teacher must be aware of strategies that will positively affect intrinsic motivation using the approaches such as positive reinforcements, students' willingness and enthusiasm (Bomia et al. (1997)). These researchers further said that, in relation to education, motivation refers to students' willingness, need, 
desire, and compulsion to participate in and be successful in the learning process; it seeks to increase the factors that move a student toward becoming more involved in the class and the subject matter. Keller (1979) also expressed that use unexpected; rewards use verbal phrase and informative feedback and external performance evaluation are used to improve intrinsic motivation. Thus, all these researches were given evidences to support the findings of the present research. Students' achievements were measured after the intervention using two types of posttests. The results were represented in Table 7.

\begin{tabular}{lllllll}
$\begin{array}{l}\text { Table } \\
\text { experimental group }\end{array}$ & $\begin{array}{l}\text { Descriptive } \\
\text { statistics }\end{array}$ & of & students' & achievements & after intervention in & the \\
\hline & N & Range & Minimum & Maximum & Mean value \\
\hline AVGPOSTTESTE & 1233 & 25 & 5.00 & 30.00 & 25.3763 \\
\hline
\end{tabular}

NB: AVGPOSTTESTE= mean average posttest marks in the experimental group after intervention

Mean value of the achievements after the intervention was near to the maximum value of range. Therefore students' achievements were enhanced while the intervention, which means the teaching learning methodologies and teaching strategies were, enhanced the students' achievements in the experimental group. Past researches were supported the current study. In this way, teaching methods were enhanced achievements in students of all level of scientific literacy (Nwagbo (2006)). At the same time, co-operative and individualized teaching methods of senior secondary school students' were effected achievement (Olatoye et al. (2011)). Students' scores in science subjects are usually below expectations Olatoye and Ogunkola (2008), Alebiosu, 1989). In this aspect, it has become necessary to seek strategies that will employ approaches that ensure and enhance better academic achievement of the science subject (Olatoye et al. (2011)). In education today, there are interesting cooperative learning methods that enable students to have an active control over their own learning and also enhance academic achievements (Olatoye (2009), Alebiosu 1989, Okebukola (1985)).

Research Question 4.2: Students' intrinsic motivation, aspirations and achievements after the intervention in the control group.

Descriptive statistics were done to examine the mean values of intrinsic motivation and aspirations of the students after the intervention process in the control group. The results were shown in the Table 8.

Table 8 Descriptive statistics of intrinsic motivation and aspirations after interventions in control group

\begin{tabular}{cccccc} 
& N & Range & Minimum & Maximum & Mean statistics \\
\hline MMAC & 1151 & 5.00 & 1.00 & 6.00 & 2.5696 \\
MAAC & 1151 & 5.00 & 1.00 & 6.00 & 2.3855
\end{tabular}

NB: MMAC: mean intrinsic motivation after the intervention of the control group, MAAC: mean aspirations after the intervention in the control group

The results revealed that, the mean values of intrinsic motivation and aspirations of the students were low. When compare the mean values of these two factors before and after interventions of the control group (Table 4, Table 8). There were no difference between the mean values of intrinsic motivation and aspirations before and after the intervention. Thus, traditional teaching method was not 
efficient to improve mean values of intrinsic motivation, and aspirations of the students in the control group. Many of the standard methods of conveying knowledge have been shown to be relatively ineffective on the students' ability to master and then retain important concepts. Learning through some methods of teaching is passive rather than active. The traditional methods (lecture, recitation methods) do not tend to foster critical and creative thinking, and collaborative problem solving (Olatoye et al. (2011)). In this aspect, the students' achievements after the intervention were measured and they were shown in the following Table 9.

\begin{tabular}{|c|c|c|c|c|c|}
\hline & $\mathbf{N}$ & Range & Minimum & Maximum & Mean value \\
\hline AVGPOSTTESTC & 1151 & 28 & 2.00 & 30.00 & 11.9096 \\
\hline
\end{tabular}

NB: AVGPOSTTESTC= mean average posttest marks in the control group after intervention

According to the above table, there was no enhancement of students' achievement after the intervention in the control group. Hence, traditional methods of teaching may not effect to the students' achievements.

\section{Research Question 4.3: Students' intrinsic motivation and aspirations with their achievements in science}

\begin{tabular}{ccc}
$\begin{array}{c}\text { Table } \mathbf{1 0} \text { Paired sample t-test of intrinsic motivation and aspirations before and after } \\
\text { interventions of experimental group }\end{array}$ & t value & Significant ( $\boldsymbol{p}$ value) \\
\hline Pair & 48.513 & .000 \\
\hline MMAE - MMBE & 53.689 & .000 \\
MAAE - MABE & 65.939 & .000 \\
\hline AVGPOSTTESTE- PRETEST &
\end{tabular}

NB: MMAE-MMBE: mean intrinsic motivation after and before intervention in experimental group, MMAE-MABE: mean aspirations after and before interventions in the experimental group, AVGPOSTTESTE- PRETEST: mean achievements after and before interventions in the experimental group

A $p$ value less than $0.05(\leq 0.05)$ is statistically significant. The $95 \%$ confidence level ( $p$ value) of all three factors was 0.00 . Thus, there was a significant difference between intrinsic motivation, aspirations and achievements after interventions in experimental group. In this aspect, teaching methodologies and teaching strategies were affected to enhance students' intrinsic motivation, aspirations and achievements in the experimental group. These results were consistence with past researches demonstrating that, student-teacher relationships in teaching-learning process and classroom climates were significantly raised secondary school achievements (Bishop (2009), Dolan and White (2007)). In the other hand, teaches play a key positive role for students aspirations (Meece and Kurtz-Costes (2001)). However, explicit encouragement for students to conceptualize and articulate future goals with teachers communicating high expectations could have a positive impact on achievement outcomes. Teachers are in a key position to encourage high aspirations while highlighting linkages between work in school and a better life beyond school in future years. In this aspect, learning methods and opportunities 
were design to communicate high expectations enhance intrinsic motivation and ultimately raise achievements (Sanders (2012)).

\begin{tabular}{|c|c|c|}
\hline Pair & t value & Significance ( $p$ value) \\
\hline MMAC - MMBC & -0.989 & .323 \\
\hline MAAC - MABC & 1.572 & .116 \\
\hline AVGPOSTTESTC-PRETEST & 0.968 & .333 \\
\hline
\end{tabular}

NB: MMAC - MMBC: mean intrinsic motivation after and before interventions in the control group, MAAC - MABC: mean aspirations after and before interventions in the control group, AVGPOSTTESTC-PRETEST: mean achievements after and before interventions in the control group.

A $p$ value less than $0.05(\leq 0.05)$ is statistically significant. The $95 \%$ confidence level ( $p$ value) of above three factors in the control group are greater than 0.05 . Thus, there is no significant difference between after and before interventions in the control group. In this aspect, traditional teaching method was not affected the students' intrinsic motivation, aspirations and achievements.

Regression is a statistical technique to formulate the analyze relationship between the dependent variable and independent variable. The independent variables were intrinsic motivation and aspirations and also the dependent variable was achievements. The aim of that case was to check how the independent variables (intrinsic motivation and aspirations) impact the dependent variable (achievements). The values of $\mathrm{r}^{2}$ shows the total variation for the achievements that could be explained by the intrinsic motivation, and aspirations. The values of $\mathrm{r}^{2}$ of the three factors in the experimental group are given in the Table 12.

\begin{tabular}{|ccc|}
$\begin{array}{c}\text { Table } \mathbf{1 2} \text { The values of } \mathbf{r}^{\mathbf{2}} \text { of intrinsic motivation aspirations with achievement in science in } \\
\text { the experimental group }\end{array}$ & Dependent variable & $\mathbf{r}^{\mathbf{2}}$ \\
\hline Independent variable & DIFACHIE & .691 \\
\hline DIFMOTIE & DIFACHIE & .687 \\
\hline DIFASPIE
\end{tabular}

NB: DIFMOTIE: difference of mean intrinsic motivation in the experimental group, DIFASPIE: difference of mean aspiration in the experimental group, DIFACHIE: difference of mean achievement in the experimental group.

The value of $\mathrm{r}^{2}$ is greater than 0.5 shows, that the model is effective enough to determine the relationships. In this aspect, the value of intrinsic motivation with achievement of the student in the experimental group was .691. Thus, there was a strong positive relationship between these two variables, and also the value of students' aspiration with achievement was 687 . Hence, there was a strong positive relationship between students' aspirations with achievement.

In past research, Bank and Finlapson (1996) and John (1996) also reported that academic achievement is highly correlated with students' motivation. Moreover, students' motivation is believed to have a significant influence on learning outcomes (Martin (2003); Martin et al. (2001, 2003); McInerney (1995); McInerney et al. (1997); Pintrich and DeGroot (1990); Schunk (1990); Yeung and Mcinerney (2005)). Students' science motivation was a better predictor of science educational and career aspirations (Chandrasena (2013)). Students' science educational and career aspirations become stronger intrinsic motivation increase. In this aspect, intrinsic motivation predicted students' science achievement more than did other 
motivational orientations (mastery, ego) (Chandrasena (2013)). On the other hand, aspirations were significantly related to different patterns of motivation and attributions predictive of academic achievement (Frank, Walkey, Mcclure and Kirsty, 2013). These were evidences to consolidate resent research findings. The values of $\mathrm{r}^{2}$ of the intrinsic motivation, and aspirations with achievements in the control group were given in the following Table 13.

Table 13 The values of $\mathbf{r}^{2}$ of intrinsic motivation aspirations with achievements in the control group

\begin{tabular}{llc}
\hline Independent variable & Dependent variable & $\mathrm{r}^{2}$ \\
DIFMOTIC & DIFACHIC & .012 \\
DIFASPIC & DIFACHIC & .006
\end{tabular}

NB: DIFMOTIC: difference of mean intrinsic motivation in the control group, DIFASPIC: difference of mean aspiration in the control group, DIFACHIC: difference of mean achievement in the control group.

The value of $\mathrm{r}^{2}$ greater than 0.5 shows, that the model is effective enough to determine the relationships. In this aspect, the values of these variables in control group are less than 0.5. Thus, there was no relationship among the independent variables and dependent variables in the control group.

\section{Research Question 5.1: Constructive suggestions to enhance meaningful learning in science in Sri Lanka}

Thematic analysis was conducted to derived meaningful themes to analyze qualitative data collected through focus group interviews conducted in every school. Three themes were derived such as,

Theme 1: Enhancement of intrinsic motivation, achievement, and aspirations through attractive teaching- learning methodologies

Intrinsic motivation, aspirations, and achievements could be enhanced attractive teaching methods. Hence, they want to continue studying science, as they feel it is more important and applicable in daily life. The following evidence is supported to the above theme from a student response.

"I willing to engage these types of attractive ways of learning. These things give positive feeling towards science in every day in my life. These learning methods new for our class specially science. I like to do practical in science more and it improve my knowledge and curiosity well. I like to be a scientist in the future. " (S3/Focus group interviews/Grade 8/PSV/22/2021).

Theme 2: Positive reinforcement on intrinsic motivation

Positive reinforcements were given by the teacher through the intervention process. The following evidence is supported by the above evidence from a student.

"When we engage science successfully, teacher always encourage us. When we engage group works or practical well, teacher always appreciates us. I like her verbal support like "very good", "excellent", and "well done". In the other hand, she gives clap on our works and presentations. It he I like it more and more. I love teacher and science." (S5/Focus group interviews/Grade 9/MRV22/10/2019).

Theme 3: Assessments on intrinsic motivation and achievement

Continuous assessments and summative assessments were done in the intervention process to investigate the students' performance. The following evidence is supported by the above theme from a student. 
"Teacher gives test papers after the end of the lesson. These papers consist multiple choice questions and also structured essay questions. I like both types of questions. I engage science after school every day at home to face the tests successfully. Therefore I can face well in every test and get high marks for every paper. I is pleasure to me and teacher also appreciates me well. I like to participate these test to improve my performance and I feel success in the classroom when I face the tests well. Hence teacher plays a great role to enhance science success. I admire her dedication. I like it." (S1/Focus group interviews/Grade 8/AMV/21/12/2020).

Moreover, the qualitative results revealed that, attractive teaching and learning methodologies, positive reinforcement and positive feedback on students are enhanced students' intrinsic motivation, aspirations and achievements in science. These aspects are very important to empower science education in Sri Lanka.

\section{CONCLUSION, SUGGESTIONS AND LIMITATIONS}

All three factors such as intrinsic motivation, aspirations and achievement measured in the study have shown excellent improvements in experimental group when compared to the control group, showing positive strong relationships in science. Student-centered teaching-learning methodologies and teaching strategies were enhanced students' intrinsic motivation, aspirations and achievements in science in the experimental group. In this aspect student centered teaching methodologies were effective and fruitful than the traditional methods of teaching science.

Moreover, this research makes some important suggestions for future activities. Thus teacher has great role to improve students' intrinsic motivation, and aspirations. Teacher should facilitate practical applications of learning of all scientific concepts relating to their real life. Teacher can enhance the learners' expectations and goals through teacher support.

In this aspect teacher's attention should be paid to improve the intrinsic motivation, aspirations and achievements of students. Teachers should be more dedicated and willing to incorporate new and attractive methods in teaching scientific concepts. Hence, teachers should promote learner centered classroom for meaningful learning.

This study was conducted in Sabaragamuwa province in Sri Lanka. Therefore it is not possible to generalize the findings of the study nationally and internationally. It is suggested to conduct the study deep and with more content in the secondary science with large sample size in order to enhance the reliability of the findings.

\section{REFERENCES}

Aikenhead, G. S. (1996). Science education: Border crossing into the subculture of science. Retrieved from https://doi.org/10.1080/03057269608560077

Aikenhead, G. S., and Jegede, O. J. (1999). Cross-cultural science education: A cognitive explanation of a cultural phenomenon. Journal of research in science teaching, 36(3), 269-287. Retrieved from https://doi.org/10.1002/(SICI)1098-2736(199903)36:3<269::AIDTEA3>3.0.CO;2-T

Alebiosu, C. O., \& Ayodele, O. E. (2006). The increasing prevalence of diabetic nephropathy as a cause of end stage renal disease in Nigeria. Tropical doctor, 36(4), 218-219. Retrieved from https://doi.org/10.1258/004947506778604797 
Alexander, M. (1989). Women in Romanticism: Mary Wollstonecraft, Dorothy Wordsworth and Mary Shelley. Macmillan International Higher Education.

Aschbacher, P. R., Li, E., \& Roth, E. J. (2010). Is science me? High school students' identities, participation and aspirations in science, engineering, and medicine. Journal of Research in Science Teaching: The Official Journal of the National Association for Research in Science Teaching, 47(5), 564-582. Retrieved from https://doi.org/10.1002/tea.20353

Bank, C., and Finlapson, W. (1980). Successful Motivation of Students in Academic Activities in McClelland, D.C. Appleton-Century-Crafts.

Bishop, S. J. (2009). Trait anxiety and impoverished prefrontal control of attention. Nature neuroscience, 12(1), 92-98. Retrieved from https://doi.org/10.1038/nn.2242

Bomia, L., Beluzo, L., Demeester, D., Elander, K., Johnson, M., \& Sheldon, B. (1997). The Impact of Teaching Strategies on Intrinsic Motivation.

Brookover, W. B., \& Lezotte, L. W. (1979). Changes in School Characteristics Coincident With Changes in Student Achievement. Occasional Paper No. 17.

Byrne, B. M., \& Shavelson, R. J. (1996). On the structure of social self-concept for pre, early, and late adolescents: A test of the Shavelson, Hubner, and Stanton (1976) model. Journal of personality and social psychology, 70(3), 599. Retrieved from https://doi.org/10.1037/0022-3514.70.3.599

Chandrasena, W., Craven, R., Tracey, D., \& Dillon, A. (2012a). A study of the relations between students' self-concepts, motivation, aspirations and achievement in high school science and chemistry.

Chandrasena, W. (2013). Seeding science success: relations of secondary students' science self-concepts and motivation with aspirations and achievement.

Deci, E., and Ryan, R. M. (1985). Intrinsic motivation and self-determination in human behavior. Springer Science \& Business Media. Retrieved from https://doi.org/10.1007/978-1-4899-2271-7

Deci, E. L., and Ryan, R. M. (2010). Intrinsic motivation. The corsini encyclopedia of psychology, 1-2. Retrieved from https://doi.org/10.1002/9780470479216.corpsy0467

Deci, Edward L., and Richard M. Ryan (2012). "Self-determination theory.".

Dolan, P., \& White, M. P. (2007). How can measures of subjective well-being be used to inform public policy?. Perspectives on psychological science, 2(1), 71-85. Retrieved from https://doi.org/10.1111/j.1745-6916.2007.00030.x

Elliott, A.J., \& Dweck, C.S. (2005). Handbook of competence and motivation. New York:

Elton, L. (1988). Student motivation and achievement. Studies in Higher Education, 13(2), 215-221. Retrieved from https://doi.org/10.1080/03075078812331377886

Fan, X., \& Chen, M. (2001). Parental involvement and students' academic achievement: A meta-analysis. Educational psychology review, 13(1), 1-22. Retrieved from https://doi.org/10.1023/A:1009048817385

Gilbert, S. W. (1991). Model building and a definition of science. Journal of Research in Science Teaching, 28(1), 73-79. Retrieved from https://doi.org/10.1002/tea.3660280107 
Guay, F., Larose, S., \& Boivin, M. (2004). Academic self-concept and educational attainment level: A ten-year longitudinal study. Self and identity, 3(1), 5368. Retrieved from https://doi.org/10.1080/13576500342000040

Guilford Press (n. d.).

Guthrie, J. T., \& Wigfield, A. (1999). How motivation fits into a science of reading. Scientific studies of reading, 3(3), 199-205. Retrieved from https://doi.org/10.1207/s1532799xssr0303_1

Marsh, H. W., \& Craven, R. G. (2006). Reciprocal effects of self-concept and performance from a multidimensional perspective: Beyond seductive pleasure and unidimensional perspectives. Perspectives on psychological science, 1(2), 133-163. Retrieved from https://doi.org/10.1111/j.17456916.2006.00010.x

Marsh, H. W., \& Hau, K. T. (2003). Big-Fish--Little-Pond effect on academic selfconcept: A cross-cultural (26-country) test of the negative effects of academically selective schools. American psychologist, 58(5), 364. Retrieved from https://doi.org/10.1037/0003-066X.58.5.364

Marsh, H. W., and Shavelson, R. (1985). Self-concept: Its multifaceted, hierarchical structure. Educational psychologist, 20(3), 107-123. Retrieved from https://doi.org/10.1207/s15326985ep2003_1

Marsh, H. W., Vallerand, R. J., Lafrenière, M. A. K., Parker, P., Morin, A. J., Carbonneau, N., \& Abduljabbar, A. (2013). Passion: Does one scale fit all? Construct validity of two-factor passion scale and psychometric invariance over different activities and languages. Psychological Assessment, 25(3), 796. Retrieved from https://doi.org/10.1037/a0032573

Mart, C.T. (2013). A passionate teacher: Teacher commitment and dedication to student learning. International Journal of Academic Research in Progressive Education and Development, 2(1), 437-442.

Martin, A. J. (2003). Boys and Motivation. The Australian Educational Researcher, 30, 43-65. Retrieved from https://doi.org/10.1007/BF03216797

Martin, A. J., Marsh, H. W., \& Debus, R. L. (2001). Self-handicapping and defensive pessimism: Exploring a model of predictors and outcomes from a self protection perspective. Journal of Educational Psychology, 93(1), 87-102. Retrieved from https://doi.org/10.1037/0022-0663.93.1.87

Martin, A. J. Marsh, H. W., \& Debus, R. L. (2003). Self-handicapping and defensive 233 pessimism: A model of self-protection from a longitudinal perspective. Contemporary Educational Psychology, 28, 1-36. Retrieved from https://doi.org/10.1016/S0361-476X(02)00008-5

McInerney, D. M. (1995). Goal theory and indigenous minority school motivation: Relevance and application. In P. R. Pintrich \& M. L. Maehr (Eds.), Advances in motivation and achievement, 9 (pp. 153-181). Greenwich, CT: JAI Press.

McInerney, D. M., Marsh, H. W., \& Yeung, A. S. (2003). Toward a hierarchical model of school motivation. Journal of Applied Measurement, 4, 335-357.

McInerney, D. M., Roche, L. A., McInerney, V., \& Marsh, H. W. (1997). Cultural perspectives on school motivation. American Educational Research Journal, 34(1), 207-236. Retrieved from https://doi.org/10.3102/00028312034001207

McLeod, S. (2007). Maslow's hierarchy of needs. Simply psychology, 1, 1-8.

Meece, J. L., \& Kurtz-Costes, B. (2001). Introduction: The schooling of ethnic minority children and youth. Educational Psychologist, 36(1), 1-7. Retrieved from https://doi.org/10.1207/S15326985EP3601_1 
Mishra, S. (2013). Science attitude as a determinant to educational aspiration in students. International Journal of Engineering Inventions, 2(9), 29-33.

Niemiec, C. P., \& Ryan, R. M. (2009). Autonomy, competence, and relatedness in the classroom: Applying self-determination theory to educational practice. School Field, 7(2), 133-144. Retrieved from https://doi.org/10.1177/1477878509104318

Nwagbo, C. (2006). Effects of two teaching methods on the achievement in and attitude to biology of students of different levels of scientific literacy. International Journal of Educational Research, 45(3), 216-229. Retrieved from https://doi.org/10.1016/j.ijer.2006.11.004

Okebukola, P. A. (1985). The Relative Effectiveness of Cooperative and Competitive Interaction Techniques in Strengthening Students' Performance in Science Classes. Science Education, 69(4), 501-9. Retrieved from https://doi.org/10.1002/sce.3730690406

Olatoye, R. A. (2009). Students' test anxiety, motivation for examinations and science achievement in junior secondary schools in Ogun State, Nigeria. International Journal of Psychology and Counselling, 1(10), 194-198. Retrieved from

Olatoye, R. A., Aderogba, A. A., \& Aanu, E. M. (2011). Effect of co-operative and individualized teaching methods on senior secondary school students' achievement in organic chemistry. The Pacific Journal of Science and Technology, 12(2), 310-319. Retrieved from

Olatoye, R. A., \& Ogunkola, B. J. (2008). Parental involvement, interest in schooling and science achievement of junior secondary school students in Ogun State, Nigeria. College Teaching Methods \& Styles Journal (CTMS), 4(8), 33-40. Retrieved from https://doi.org/10.19030/ctms.v4i8.5563

Pascarella, E. T. (1984). College environmental influences on students' educational aspirations. The Journal of Higher Education, 55(6), 751-771. Retrieved from https://doi.org/10.2307/1981512

Pintrich, P. R., \& DeGroot, E. V. (1990). Motivational and self-regulated learning components of classroom academic performance. Journal of Educational Psychology, 82, 33-40. Retrieved from https://doi.org/10.1037/00220663.82.1.33

Reynolds, R., \& Chiu, M. M. (2012, July). Contribution of motivational orientations to student outcomes in a discovery-based program of game design learning. In International Conference of the Learning Sciences (ICLS).

Ryan, R. M., Connell, J. P., \& Plant, R. W. (1990). Emotions in nondirected text learning. Learning and individual differences, 2(1), 1-17. Retrieved from https://doi.org/10.1016/1041-6080(90)90014-8

Ryan, R. M., \& Deci, E. L. (2000). Self-determination theory and the facilitation of intrinsic motivation, social development, and well-being. American psychologist, 55(1), 68. Retrieved from https://doi.org/10.1037/0003066X.55.1.68

Ryan, R., \& Deci, E. (2000). Intrinsic and extrinsic Motivations: Classic definitions and new directions. Contemporary Educational Psychology, 25, 54-67. Retrieved from https://doi.org/10.1006/ceps.1999.1020

Sanders, M. R. (2012). Development, evaluation, and multinational dissemination of the Triple P-Positive Parenting Program. Annual review of clinical psychology, 8, 345-379. Retrieved from https://doi.org/10.1146/annurevclinpsy-032511-143104 
Schunk, D. H. (1990). Introduction to the special section on motivation and efficacy. Journal of Educational Psychology, 82, 3-6. Retrieved from https://doi.org/10.1037/h0092681

Serin, H. (2018). The use of extrinsic and intrinsic motivations to enhance student achievement in educational settings. International Journal of Social Sciences \& Educational Studies, 5(1), 191-194. Retrieved from https://doi.org/10.23918/ijsses.v5i1p191

Shavelson, R. J., Hubner, J. J., \& Stanton, G. C. (1976). Self-concept: Validation of construct interpretations. Review of educational research, 46(3), 407-441. Retrieved from https://doi.org/10.3102/00346543046003407

Shrake, D. L., Elfner, L. E., Hummon, W., Janson, R. W. and Free, M. (2006). What is science?.

Sproule, J., Wang, C. J., Morgan, K., McNeill, M., \& McMorris, T. (2007). Effects of motivational climate in Singaporean physical education lessons on intrinsic motivation and physical activity intention. Personality and Individual Differences, 43(5), 1037-1049. Retrieved from https://doi.org/10.1016/j.paid.2007.02.017

Taormina, R. J., \& Gao, J. H. (2013). Maslow and the motivation hierarchy: Measuring satisfaction of the needs. The American journal of psychology, 126(2), 155177. Retrieved from https://doi.org/10.5406/amerjpsyc.126.2.0155

Tharmaseelan, N. (2007). Tertiary education in Sri Lanka: Issues and challenges. Bulgarian Journal of science and education policy, 1(1), 173-190.

Treagus, S., Wright, C., Baker-Austin, C., Longdon, B., \& Lowther, J. (2021). The Foodborne Transmission of Hepatitis E Virus to Humans. Food and environmental virology, 1-19. Retrieved from https://doi.org/10.1007/s12560-021-09461-5

Ventegodt, S., Merrick, J., \& Andersen, N. J. (2003). Quality of life theory III. Maslow revisited. TheScientificWorldJOURNAL, 3, 1050-1057. Retrieved from https://doi.org/10.1100/tsw.2003.84

Wang, J., \& Staver, J. R. (2001). Examining relationships between factors of science education and student career aspiration. The Journal of Educational Research, 94(5), 312-319. Retrieved from https://doi.org/10.1080/00220670109598767

Yeung, A. S., \& Mcinerney, D. M. (2005). Students' school motivation and aspiration over high school years. Educational Psychology, 25(5), 537-554. Retrieved from https://doi.org/10.1080/01443410500046804

Zeyer, A., and Wolf, S. (2010). Is there a relationship between brain type, sex and motivation to learn science?. International Journal of Science Education, 32(16), 2217-2233. Retrieved from https://doi.org/10.1080/09500690903585184 